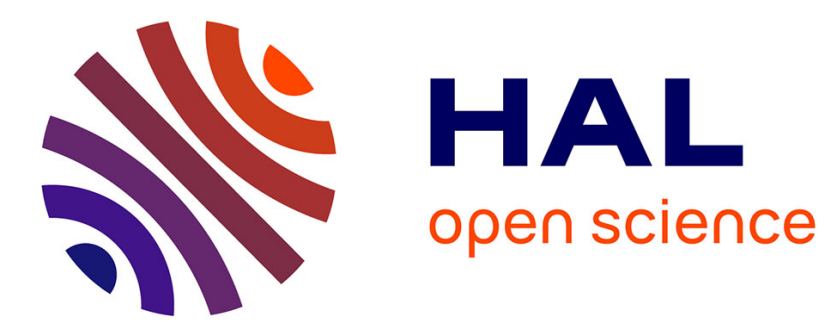

\title{
The Euro Sovereign Debt Crisis and the Built-in Instability of the Euro
}

\author{
Radu Vranceanu
}

\section{To cite this version:}

Radu Vranceanu. The Euro Sovereign Debt Crisis and the Built-in Instability of the Euro. 2013. hal-00766691v2

\author{
HAL Id: hal-00766691 \\ https://essec.hal.science/hal-00766691v2 \\ Preprint submitted on 12 Mar 2013
}

HAL is a multi-disciplinary open access archive for the deposit and dissemination of scientific research documents, whether they are published or not. The documents may come from teaching and research institutions in France or abroad, or from public or private research centers.
L'archive ouverte pluridisciplinaire HAL, est destinée au dépôt et à la diffusion de documents scientifiques de niveau recherche, publiés ou non, émanant des établissements d'enseignement et de recherche français ou étrangers, des laboratoires publics ou privés. 


\title{
The Euro Sovereign Debt Crisis and the Built-in Instability of the Euro
}

\author{
Research Center \\ ESSEC Working Paper 1211
}

2012

Radu Vranceanu 


\title{
The Euro sovereign debt crisis and the built-in instability of the Euro.
}

\author{
A shorter version is forthcoming in: Eurozone and the Future of Europe, Eds. J. Stein, D. Daianu, R. \\ Kumar. Prentice Hall 2013.
}

\author{
Radu Vranceanu \\ ESSEC Business School \\ 95021, Cergy, France \\ E-mail: vranceanu@essec.fr
}

December 25, 2012

\begin{abstract}
.
This policy paper aims at presenting the key facts related to the Euro sovereign debt crisis that occurred in the interval 2010-2012. It points out some main coordination failures that are at the origin of the crisis, and comments on the effectiveness of various stabilization measures undertook by governments and the EU institutions.

Keywords: Euro sovereign debt crisis, ECB, EU, coordination failure, illiquidity, fiscal and monetary policy.
\end{abstract}

\section{An introductory comment}

After decade of hope and enthusiasm, the Euro sovereign debt crisis that began in late 2009 and still continues throughout 2012 brought to light several major flaws of the single currency project.

In any group where individual decision makers reap the gains of their action, but share its costs with all the other members of the group, there is a built-in incentive to free ride. If the Euro fathers tried to bound opportunistic behavior of member country governments through treaties and various regulations, they could not imagined all the possible spillover effects, and it would be unfair to criticize them for this. The origin of economic crises lies precisely in the bounded rationality of human beings, and those who believe that everything can be planned or controlled by a group of wise experts are just over-optimistic. In this chapter we argue that one main omission in the Euro design was proper consideration of the 'risk of illiquidity', i.e. the possibility that in the absence of a genuine lender-of-lastresort, investors might have good reasons to shun bonds issued by otherwise solvent governments. Given its peculiar financial structure, Euro area countries can be victims of illiquidity-driven crises quite frequent in the developing world. 
This study aims to present the essential dimensions of the Euro sovereign debt crisis, to analyze its causes, and to comment on the efficiency of various measures taken in order to fight it. The first section briefly recalls the history of the European integration process. Section 2 introduces the main facts about the evolution of public debts and deficits in the Euro area. We introduce some theoretical considerations in section 3 . Section 4 analyses the on-going crisis. In the last section we will comment on what institutional changes could help the Euro area countries to recover.

\section{The European integration process and the advent of the Euro}

In the aftermath of the Second World War, European citizens shared the belief according to which an economically integrated Europe would prevent European peoples from fighting each other again. If this argument still remains valid, many younger European citizens, who did not go through the war atrocity, are supporting the European project insofar as it associated to an image of modernity, openness, and, ultimately, higher living standards. For many years major political parties in the European countries adopted a pro-European stance, and polls validated their strategy. With a few exceptions Europe bashing was the trademark of extremists of all boards.

In the years that followed the signature of the treaty of Rome in 1957, the steady pursuit of the project of an economically integrated Europe advanced both intensively, with new markets and institutions being placed under supra-national European supervision, and extensively, with new countries joining the European common project. The founding group of the European Economic Community was made up of six countries; now the European Union (EU) gathers 27 countries, the biggest wave of enlargement having taken place in 2005-2007, with the integration of ten Eastern European countries, along with Malta and Cyprus. So far, the most important achievement of the European integration process has been the creation of a genuine "single goods market", with EU countries agreeing on suppressing all trade barriers between them, imposing a single tariff with the rest of the world, and placing trade policy in the hands of the European Commission, the executive arm of the EU. The internal cohesion of the single market for goods was fostered by the simultaneous implementation of a uniform competition policy, which placed antitrust rules under the responsibility of the EU and banned national industrial policies, a euphemism for protectionism. Progress in the integration of the market for services was somehow slower, since it brings into the picture difficult issues, such as the wage gap between countries with different development levels.

Integration of factor markets is also a difficult and still unachieved process. As stated in the Maastricht Treaty in 1992, labor can in principle travel freely from one country to another, but administrative and psychological costs are still very high. In 2010 the share of foreigners born in a EU-15 country (the Western group), living in a EU-15 country is as small as 1.8 per cent of the population. The proportion of immigrants from Eastern Europe in the same EU-15 countries is 1.3 per cent (European Commission, 2011). In the 1980s all rich countries went through an ambitious process of liberalizing movements of capital. The EU countries did implement the main steps toward integrating trade in financial assets; investors from any EU country can buy bonds, shares, foreign exchange, and any other assets from any EU country. However, when it comes to the banking and insurance sector, the protectionist demons were alive and well, and quite often governments found insidious ways to block foreign banks to take- 
over national banks. As a result, a true pan-European market in banking services (less so in insurance) never emerged, and outrageous abuses by cartels, set up by national banks, often make the first page of economic newspapers.

On top of all these, in 1992 signatories of the Maastricht Treaty planned for implementation of a monetary union, and in 1999 twelve founding member countries created the euro. In 2012, 17 of the 27 EU countries have adopted the euro (Table 1). Among the rich EU countries, notable opt-outs are the UK, Sweden and Denmark. The monetary policy and the management of the euro were assigned to a newly created institution, the European Central Bank (ECB). The key objective of the new central bank was maintaining price stability in the euro area.

Proponents of the integrated Europe claimed that this new move would foster convergence between Euro economies, and would consolidate the single market. Among the most important expected benefits, experts pointed to savings on transaction costs, mainly on hedges against currency fluctuations. In countries with a poor performance in terms of inflation, the new central bank, free of political influence and pursuing an overriding goal of price stability, was expected to bring the needed monetary discipline.

A few critics pointed out that most of the European countries have rigid labor markets; thus, dropping the exchange rate adjustment mechanism could be dangerous, should their economy be hit by countryspecific shocks. Others have noticed that a single currency combined with independent fiscal policies opens the door for fiscal free-riding; to counter this criticism, in 1999 the Euro governments agreed to sign the Stability and Growth Pact (S\&GP), preventing deficits higher than 3 per cent of the GDP, and urging governments to bring public debt below 60 per cent of the GDP 'as soon as possible'. Countries that would not comply with the deficit criterion would have been subject to sanctions. Unfortunately, governments never took this pact seriously and neither did the European Commission.

Milton Friedman delivered the most prominent criticism against the Euro in several speeches in 2001, following early arguments he brought in 1997. Milton Friedman was not against Europe, nor against the single EU market in goods and services. He just tried to call attention to the possibility that the implementation of a single currency might expose European people to adversity, should an asymmetric shock hit their economies. In a famous debate with Robert Mundell (Mundell and Friedman, 2001), he stated:

'If the residual flexibility is enough, or if the existence of the euro induces a major increase in flexibility, the euro will prosper. If not, as I fear is likely to be the case, over time, as the members of the euro experience a flow of asynchronous shocks, economic difficulties will emerge. Different governments will be subject to very different political pressures and these are bound to create political conflict, from which the European Central Bank cannot escape' (Milton Friedman, 2001).

In general, such calls for caution were dismissed as being motivated by negative sentiments against a rising European currency that was born to replace the dollar as a reserve currency. 
At first the euro seemed to deliver on all promises. Under the banner of highly respected Presidents Willem Duisenberg and Jean-Claude Trichet - the ECB achieved its fundamental goal (price stability): on average, between 1999 and 2012, the inflation rate was close to two per cent, in line with the official quantitative target of the ECB (Figure 1). The bank followed an aggressive version of the Taylor rule, and pushed up the main instrument, the interest rate on its 7-day loans to banks whenever expected inflation moved away from the target (see Fourçans and Vranceanu, 2007; Wouter-Botzen and Marey, 2010).

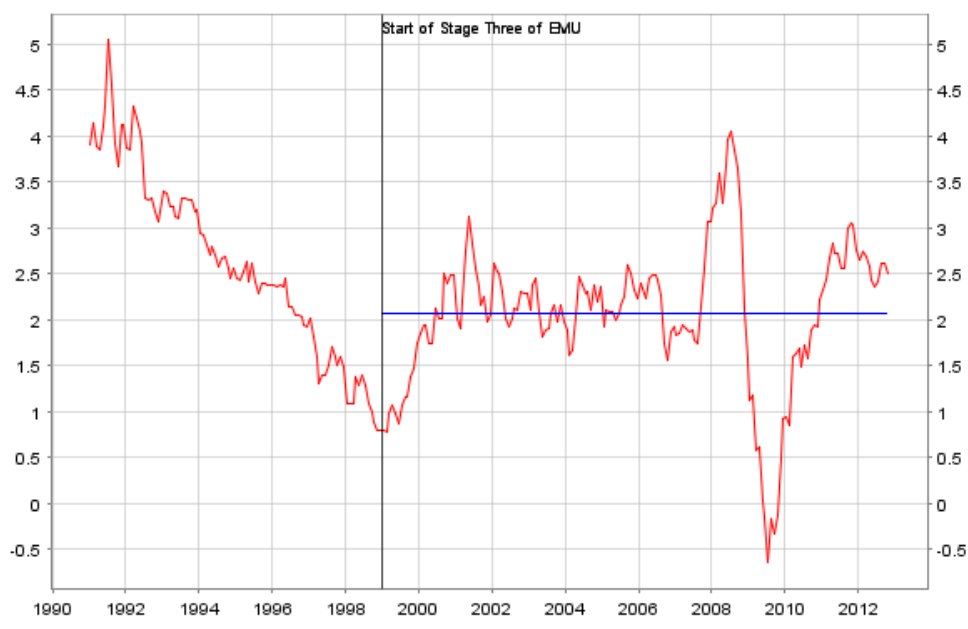

Figure 1. Average inflation rate in the Euro are. Source: ECB Statistical Data Warehouse

Compared to the post-Great Recession (2007-2009) period, the first years of the euro were an easy ride. The ECB had to overcome a difficult moment in its first months of existence when the euro sharply depreciated against the dollar. The coordinated intervention of the major central banks in October 2000 pushed back the euro on an appreciating trend that lasted for almost eight years. With ups and downs, the euro moved from the lowest rate of 0.80 cent/dollar in October 2000 to a high of 1.59 cents/dollar in July 2008. Long-run currency appreciation should support inflows of short-term capital toward the Euro area, and many US hedge funds actively bought euro assets. Highly leveraged Euro area banks found there a source of cheap money.

The 1992 decision to create a single currency coincided with the beginning of declining yields of longterm Treasury bonds in the Euro area (Figure 2). Whether this trend was representative of an excess of savings, with an aging rich world and a Chinese government aggressively pushing exports (and thus piling dollars and euros), or just reflect the lower inflation expectations in Euro countries with traditionally loose monetary policies, this is open to debate. What should be emphasized is that low interest rates come with a strong incentive to borrow, both for the private sector and the public administration. 


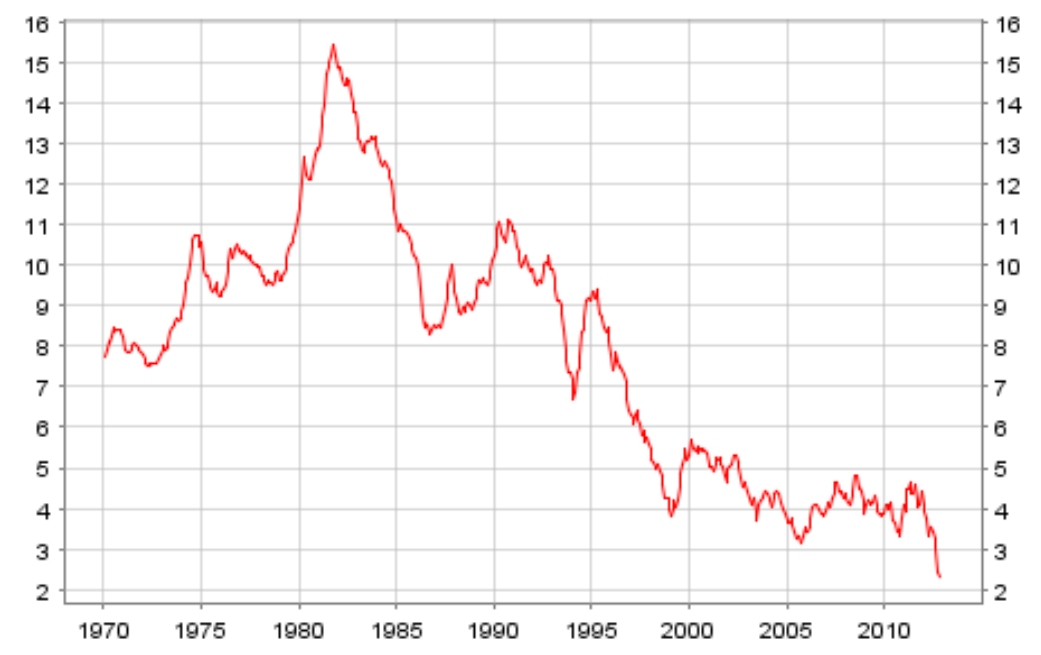

Figure 2. Euro area (changing composition) 10-year Government benchmark bond yield.

\section{Source: ECB Statistical Data Warehouse}

Furthermore, the introduction of the euro prompted long term interest rates of countries belonging to the Euro area to converge. Traditional high yields of peripheral countries vanished almost instantaneously in 1999, and, until 2007, spreads with the German Bunds never exceeded 70 basis points. Of course, if in the past high yields revealed a devaluation risk, when moving to a single currency the scope for devaluation disappears, and the devaluation premium should vanish. Yet we know today (late 2012), that Euro area countries were quite different in terms of fundamentals, both with respect to the engines of growth before 2007, as with respect to their capacity to absorb shocks. Then why did investors not price correctly these differences? The strong political marketing campaign in favor of the euro, backed by the actual achievements of the new currency in the first years, would explain the 'norisk illusion'. A poor understanding of the interaction between the risk of illiquidity and the risk of insolvency can also provide an explanation. Before 2008 the idea that the government of a rich EU country can default could hardly be imagined, either because 'naïve' investors had faith in the ability of rich-country governments to service the debt, or because they believed that contrary to what the ECB statute required, the central bank would end-up by bailing-out distressed governments (Coeuré, 2012).

\section{Debt and deficits in Europe: the historic perspective}

So from 1957 to present times, successive waves of European policymakers battled to create a single market for goods, services, and factors. They lately pushed towards the adoption of a single currency. However, when it came to the most important economic prerogative of a government, the right to tax (and eventually to spend), they never considered the idea to place it at the same level as trade or monetary policy, i.e. at the supranational level. The idea that European economic integration can proceed on all dimensions except the fiscal one is deeply anchored in the European project. As a consequence, over time the budget of the European Commission, has been close to one per cent of the GDP of member countries, compared with an average tax rate in the EU27 as high as 44.7 per cent of GDP in 2011. 
In the last twenty years EU governments made some shy attempts to coordinate on VAT taxes (currently in a range between 19 per cent and 22 per cent of the sales), but policymakers did not miss the opportunity to give special exemptions. In general, most movements followed a trend of reducing corporate taxes, but the rate still varies a lot from one country to another, from 12.5 per cent in Ireland to about 33 per cent in France and Italy in 2011, and 29.5 per cent in Germany (as compared to an EU average rate of 20.5 per cent). Variations in wealth and income taxes on labor and capital are even larger from one country to another. On the spending side most Euro-area governments are advocates of some form of welfare state, with large spending rates required to back publicly run plans in health care, education and retirement. There are however large differences with respect to the 'philosophy' and effectiveness of public spending from one country to another.

The deficit bias and the rising debt-to-GDP ratio are not specific to EU countries, but seem to be a characteristic of the rich world. Data provided by Checchetti et al. (2010) (figure 3) are more than frightening, particularly if we take into account that debt accounts for only the 'visible' part of the total liabilities of the government. The no less important 'invisible' part includes all additional expenses on health care and pensions related to an aging population, and environment protection that will call for future deficits and additional debt in the years ahead. In order to contain the additional liabilities, in the last few years, some countries (for instance Germany, France, Italy) managed to push more aggressively toward revamping the public retirement schemes, mainly by raising the retirement age.

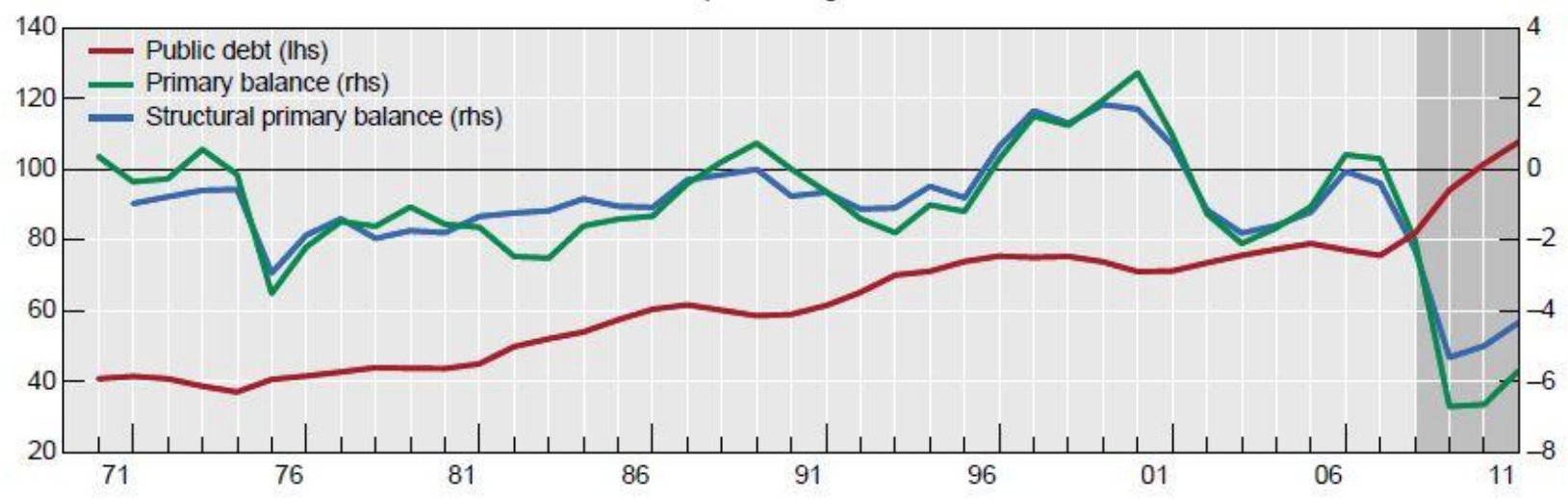

Weighted average based on 2005 GDP and PPP exchange rates of economies cited and data availability. Australia, Austria, Belgium, Canada, Denmark, France, Finland, Germany, Greece, Ireland, Italy, Japan, the Netherlands, New Zealand, Norway, Portugal, Spain, Sweden, Switzerland, the United Kingdom and the United States. Raw data sources: OECD; BIS Calculations.

Figure 3. Government gross public debt and primary fiscal balance in industrial economies as a percentage of GDP. From Checcetti et al. 2010.

Actually, in the period from 1999 to 2007, EU countries managed to keep debt-to-GDP ratios stable, but high debt countries did not achieve substantial progress in reducing it. Most amazing, in 2005, under pressure from Germany and France, which at that time were running an excessive deficit, the sanction 
criteria were relaxed to allow for more 'flexibility'. This buried for good the credibility of the Pact, and, when the Great-Recession hit the EU countries in 2008, governments had absolutely no remorse to carry out abyssal deficits (as large as 6.3 per cent of GDP on average in the Euro area in 2009).

And why should they care if investors kept providing them with cheap money? Until the beginning of 2009 (thus, including the Great Recession) spreads between interest rates on Euro-area sovereign bonds were still negligible (Figure 4). The myth of an infinite demand for Treasury bonds was alive and well (but not for long!).

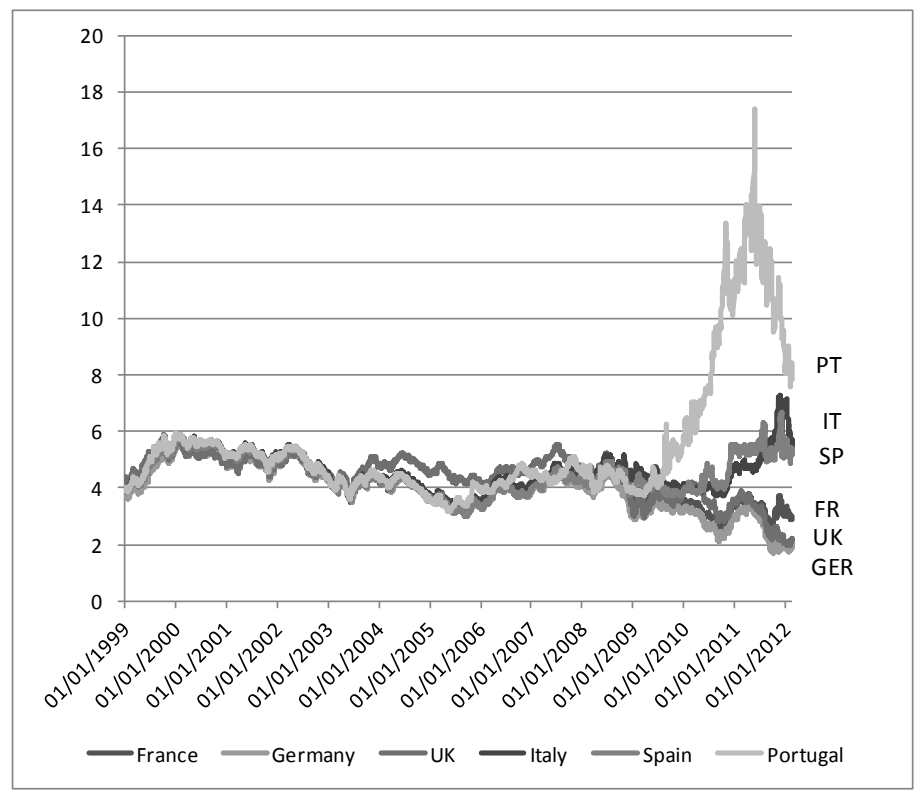

Figure 4. 10-year Government bond yield. Source: Bloomberg

Public debt jumped from 66.4 per cent in 2007 to 80.0 per cent of GDP in 2009 (Figure 5), way above the 60 per cent target of the Stability and Growth Pact.

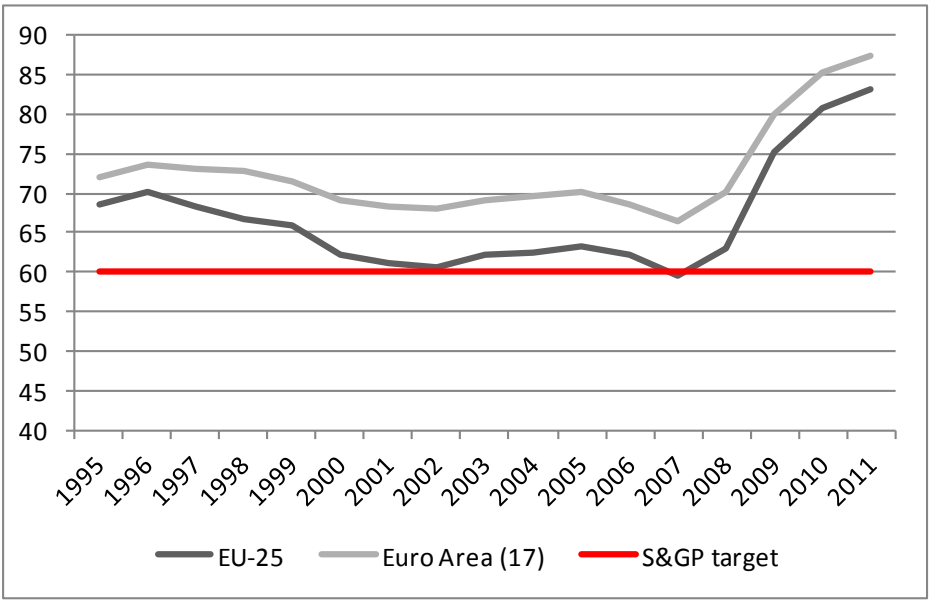

Figure 5. Public debt in the EU-25 and the Euro areaas a percentage of GDP. Source: Eurostat 
The storm began in October 2009. After a surprise revision of the foreseen public deficit from 6 per cent to 12.7 per cent of GDP, with a public debt as high as 120 per cent of the GDP (350 billion euros), investors started shunning Greek bonds. Yields on 10-year Greek bonds began to rise (from 4.4 per cent in October 2009, to 9.8 per cent one year later), and rating agencies engaged a long downgrade process moving in pair with an accelerated raise in Credit Default Swaps spreads. As shown by data in Figure 6, Greece never complied with the S\&GP 3 per cent deficit criterion, (they forged the national statistics on the deficit in 2001, when they joined the EMU) but until 2008 high growth rates created an illusion of stability.

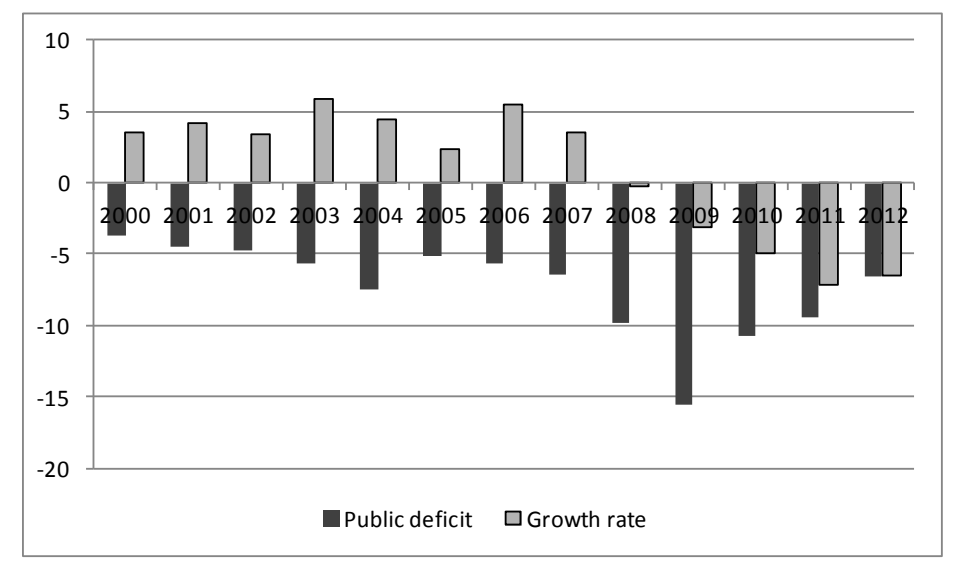

Figure 6. Greece: Public deficit as a percentage of the GDP and annual growth, 2000-2012. Source: Eurostat

In April 2010 a downgrade to junk status closed the market for Greek Treasury bonds, which prompted France, Germany and the IMF to set up an emergency rescue plan of 110 billion euro. France and Germany were the most concerned by a would-be Greek default since a large chunk of the Greek debt was held by French and German banks. The Greek syndrome spread to bond markets rapidly in Ireland, Portugal and Spain, although the economic fundamentals and difficulties differed greatly from one country to another. A second EU support plan, this time conveyed through an emergency EU special purpose investment vehicle - the European Financial Stability Facility (EFSF) - provided an additional 100 billion euro in March 2011. Finally, Greece ended up partially defaulting on its public debt in March 2012; private holders of 177 billion euro Greek bonds had little choice but to swap them against new bonds with a face value of 46.5 per cent of the initial one, which then traded in the market at about 25 per cent of the face value. The Collateral Debt Swaps (CDS), special contracts providing insurance against the default, were exercised. For the first time after the WW2, a rich country defaulted on its sovereign debt. At the end of 2012 the situation of Greece was not better with a debt-to-GDP close to 175 per cent, a huge deficit (including a primary deficit), and free-falling output. Successive waves of street protests only reinforced chances that extreme left political forces would get to rule the country, a step that would move Greece closer to a second debt default (70 per cent of the bonds are now hold by official creditors: EU governments, IMF, ECB). One can reasonably ask whether at some point the costs of maintaining Greece in the Euro area will not exceed benefits of its exit. Furthermore, out of the Euro the Greek government could run a public deficit needed to protect the poorest persons living on state 
support and public services; but in this case, it could charge the deficit on the wealthiest, by monetizing it and letting inflation taking its toll.

Table 1 presents some important data (debt, deficit, growth) for the EU 27 countries. During the 19962011 period only six out of the $27 \mathrm{EU}$ countries managed to reduce their debt-to-GDP ratio. At the end of the second quarter of 2012, the public debt of the Euro area reached 8500 billion euro, or 90.0 per cent the region's GDP.

\begin{tabular}{|c|c|c|c|c|c|}
\hline Country & $\begin{array}{c}\text { Debt-to-GDP } \\
1996 \\
\end{array}$ & $\begin{array}{c}\text { Debt-to-GDP } \\
2011 \\
\end{array}$ & $\begin{array}{c}\text { Av. growth rate } \\
1996-2011 \\
\end{array}$ & $\begin{array}{l}\text { Av. deficit-to- } \\
\text { GDP 1996-2011 }\end{array}$ & $\begin{array}{c}\text { Euro } \\
\text { membership }\end{array}$ \\
\hline Austria & 68,1 & 72,2 & 2,2 & $-2,2$ & 1999 \\
\hline Belgium & 127,2 & 98 & 1,9 & $-1,5$ & 1999 \\
\hline Bulgaria & 108,3 & 16,3 & 2,6 & $-0,1$ & No \\
\hline Cyprus & 53,1 & 71,6 & 3,0 & $-3,3$ & 2008 \\
\hline Czech Republic & 11,9 & 41,2 & 2,8 & $-3,9$ & No \\
\hline Denmark & 69,4 & 46,5 & 1,3 & 1,0 & No \\
\hline Estonia & 7,6 & 6 & 5,0 & 0,2 & 2011 \\
\hline Finland & 57 & 48,6 & 2,8 & 1,9 & 1999 \\
\hline France & 58 & 85,8 & 1,7 & $-3,5$ & 1999 \\
\hline Germany & 58,5 & 81,2 & 1,4 & $-2,3$ & 1999 \\
\hline Greece & 99,4 & 165,3 & 1,9 & $-7,4$ & 2001 \\
\hline Hungary & 72,4 & 80,6 & 2,3 & $-5,3$ & No \\
\hline Ireland & 71,7 & 108,2 & 4,7 & $-3,0$ & 1999 \\
\hline Italy & 120,2 & 120,1 & 0,9 & $-3,4$ & 1999 \\
\hline Latvia & 13,9 & 42,6 & 4,5 & $-2,5$ & No \\
\hline Luxembourg & 7,4 & 18,4 & 3,8 & $-2,0$ & 1999 \\
\hline Lithuania & 13,8 & 38,5 & 5,2 & $-3,7$ & No \\
\hline Malta & 40,1 & 72 & 1,7 & $-5,5$ & 2008 \\
\hline Netherlands & 74,1 & 65,2 & 2,2 & $-1,5$ & 1999 \\
\hline Poland & 43,4 & 56,3 & 4,4 & $-4,7$ & No \\
\hline Portugal & 58,2 & 107,8 & 1,6 & $-4,8$ & 1999 \\
\hline Romania & 10,6 & 33,3 & 2,6 & $-3,8$ & No \\
\hline Slovakia & 31,1 & 43,3 & 4,3 & $-5,7$ & 2009 \\
\hline Slovenia & 21,9 & 47,6 & 3,1 & $-3,0$ & 2007 \\
\hline Spain & 67,4 & 68,5 & 2,7 & $-2,7$ & 1999 \\
\hline Sweden & 73,3 & 38,4 & 2,7 & 0,7 & No \\
\hline United Kingdom & 51,3 & 85,7 & 2,3 & $-3,4$ & No \\
\hline
\end{tabular}

Table 1. Public debt, public deficit and growth in the EU 27 countries. Source: Eurostat 


\section{Some theory}

For an individual, a higher borrowing cost would limit his spending enthusiasm. He knows that lenders can confiscate all his wealth should he default. For a defaulting government, confiscation is not an option, and experience shows that governments in developing countries have repudiated their debt rather frequently (Reinhart and Rogoff, 2009).

The borrowing cost is not a tight constraint for a government as long as it can pay back the maturing debt by borrowing. Assuming that debt is issued for one year only, denoting public debt by $D$, interest rate by $i$, and the primary deficit by $Z$ (defined as the positive difference between public spending on all items except interest $G$, and taxes $T$ ), the 'magic' budget identity for the government can be written as:

$$
D_{\mathrm{t}-1}(1+i)+Z_{\mathrm{t}}=D_{\mathrm{t}}
$$

where $t$ is the time index. This formula tells us that you can pay back your debt and the interest, and even spend more than your income (run a deficit $Z>0$ ), if you find nice people in the world willing to lend you for another round. Of course, governments issue debt with various maturities, from a few months to thirty years, and even more. Hence, every year only a share of the total debt must be rolled over. The longer the average maturity, the less substantial are refinancing needs during one year. For instance, in 2011 the average maturity for French and Italian public debt was about seven years; it was 14 years for the UK.

This being said, even if only a tenth of the public debt comes to maturity and instead of a deficit, the government makes a primary surplus (taxes are higher than spending) as high as five per cent of GDP, this would not suffice to pay for a debt service higher than 50 per cent of the GDP. This simple back-ofthe-envelope calculation explains why the majority of Euro area countries are critically dependent on the willingness of investors to buy their new debt.

Whether over time a borrower can pay back his debt or not depends to a large extent on his future flow of income. In turn, a government's income depends on the effectiveness of the taxation system, the tax rate, and the total national output gauged by a standard measure such as the Gross Domestic Product (GDP). It thus became the norm to analyze the debt sustainability issue by considering the debt-to-GDP ratio, denoted by $d=D e b t / D G P$. Let us denote the nominal GDP by $Y$, the nominal growth rate of GDP by $g$, such as implicitly defined by $Y_{\mathrm{t}}=Y_{\mathrm{t}-1}(1+g)$, and let us assume that the deficit over GDP is given; we denote it by $z$ (with $z=Z / Y$ ). Then, if we divide both terms in formula (1) by $Y_{t}$, after some calculations, we get:

$$
d_{\mathrm{t}}-d_{\mathrm{t}-1}=d_{\mathrm{t}-1}(i-g) /(1+g)+z
$$

The debt-to-GDP rises from one period to another if $\left[d_{\mathrm{t}-1}(i-g) /(1+g)+z\right]>0$ and declines if $\left[d_{\mathrm{t}-1}(i-g) /(1+g)\right.$ $+z]<0$. For instance, with a initial debt as high as 90 per cent of GDP, a nominal growth rate of 3 per cent per year, and an interest rate of 5 per cent per year, the debt-to-GDP would decline only if the country produces a primary surplus( $s=-z)$ higher than 1.75 per cent of GDP. 
If the debt-to-GDP increases year after year, the debt path is 'unsustainable': sooner or later the government will reach its 'solvency limit' above which the debt cannot be paid back, whatever the measures implemented. It is difficult to say where this limit is, but, for sure, there is one. The total public wealth is made-up of the market value of national assets (land, property, tradable natural resources, national art, and so on) and the discounted value of future income, which is limited (in theory) by the annual GDP. Even if this amount can be very large, it is finite.

So if the government runs primary deficits and the interest rate on public debt exceeds the nominal growth rate, the country will end up defaulting at some point. To the contrary, if growth rates are higher than interest rates and the country is delivering a primary surplus $s=(-z)>0$, then the debt is on a sustainable path. Unfortunately, not all the parameters of this relationship are under the direct control of the government. Higher taxes and lower spending may turn the deficit into a surplus, but there is no short-run solution to turn sluggish growth into roaring growth. Furthermore, fiscal consolidation should have an adverse effect on growth in the short run. Long term growth most often depends on the capacity of firms to innovate and their competiveness (itself grounded in the flexibility of the labor market and a light business regulation), a judicial system that protects private property and the respect of contracts, a global environment favorable to R\&D, and so on.

One might notice that expression (2) refers to nominal growth, not real growth. If real growth is sluggish, why not resort to high inflation in order to foster the nominal growth rate $g$ ? If the debt has a long maturity, this not-so-moral 'smart' solution might work, since the bulk of the interest rate is given. However, if the debt is short-term (or is inflation indexed), the 'trick' will not work, because of the oftenneglected 'Fisher Law': the nominal interest rate is the sum between the real interest rate and expected inflation. Whenever investors expect inflation to edge up, interest rates will rise in pair. The difference $(i-g)$ is not affected by higher expected inflation.

The Euro founders had faith in the rule-of-thumb according to which the risk of default should be negligible if public debt is below 60 per cent of the GDP (as required by the S\&GP). In the early 1990s rich countries, such as Japan or Italy, used to run high public debts and faced no difficulty in rolling it year after year. However, the world economy in 2012 is not the same as in 1992. In particular, managing public debt without a lender-of-last-resort is not the same as managing public debt with a central bank behind it. Whether investors accept to hold the debt of a government depends first on their beliefs, and human beliefs, by nature, are very volatile. They respond to soft signals, to rumors and fashions, and sometimes move without a change in fundamentals of the asset. Furthermore, according to ECB data, at the end of 2011, 51 per cent of the public debt in the euro area was held by non-residents (Figure 8), whose expectations can be even more volatile than residents' expectations (who can be better informed about the real situation of their economy).

To be a little more specific about the default mechanism, let us consider the situation described in Figure 7. Given the exponential path of the debt-to-GDP ratio, the government in country A will reach the insolvency threshold in 20 years. 

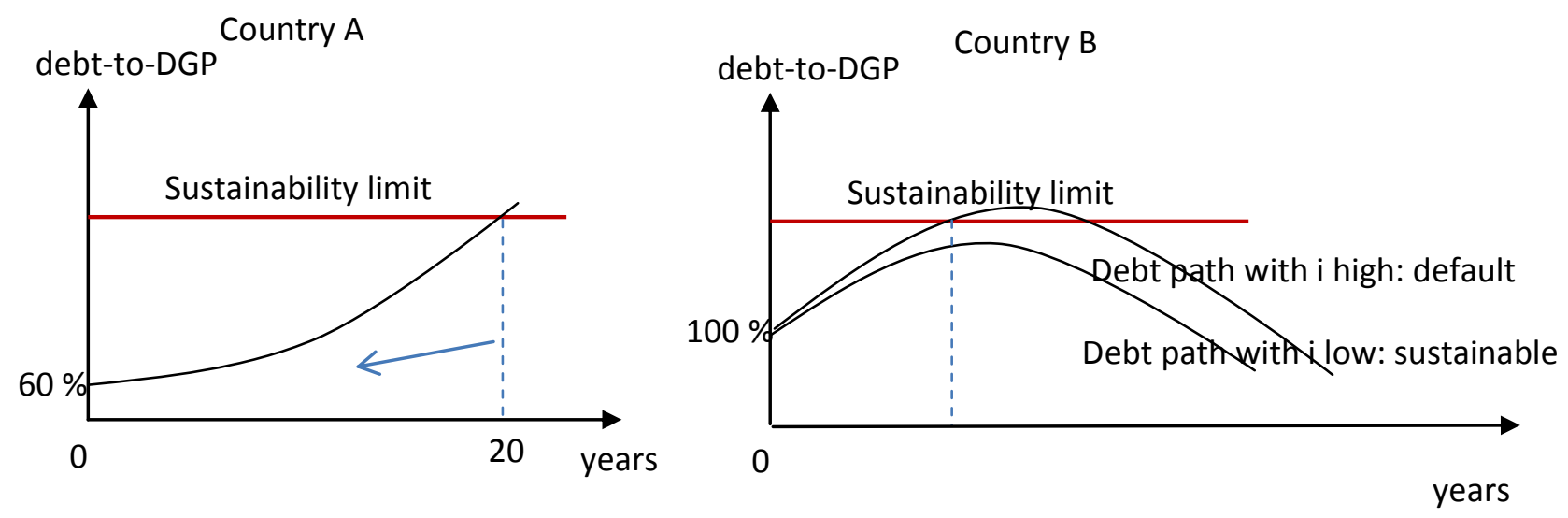

Figure 7. Debt trajectories, risk and timing of default

But in this case there is no reason for investors in the $19^{\text {th }}$ year to lend funds to that government, because they know that one year later the government will not be able to borrow; thus, they it will not be able to reimburse investors. Therefore, the government will be in a position to default after 19 years. But in this case, investors in the $18^{\text {th }}$ year have no reason to lend, and the government will default in the $18^{\text {th }}$ year... and so on; this backward rationale explains why investors, foreseeing that the debt is on an unsustainable path, would refuse lending immediately, and prompt the government to default at once (in $\mathrm{t}=0$ ).

Let us consider the case of country B with low borrowing costs (small $i$ ). The debt trajectory is represented by the lower curve, where the limit of sustainability is never reached. Investors have no reason to shun its bonds. However, should they have the slightest doubt, this would push-up the interest rate, and the trajectory would shift toward the upper path (high i), leading to immediate default.

This elementary analysis shows that the risk of default by insolvency and the risk of default by illiquidity are strongly interconnected. Furthermore, without special safeguards, the default equilibrium is always possible, because default is a self-fulfilling prophecy: should investors ask for very high interest rates, the debt moves on an explosive path where a normal primary surplus cannot avoid default. This 'multiple equilibria' situation makes debt management a very complex issue. In general, in standard two-tier banking systems, central banks can play a role of 'lender-of-last-resort'. For instance, nothing prevents the Fed or the Bank of England to buy Treasuries. ${ }^{1}$ In these countries, as long as the debt is below the sustainability threshold, the central bank can buy this debt and thus prevent interest rates from rising (at least, they can do so as long as inflation expectations are under control). Since the poor equilibrium cannot happen, investors keep on buying this debt and the interest rate stays low without the intervention of the central bank. However, should this country reach the solvency threshold at some

\footnotetext{
${ }^{1}$ Actually, both these central banks have massively bought Treasuries in the 2008-2012 period (their balance sheet more than doubled over the period!), although the stated direct goal was not to bail out the government, but to provide commercial banks with liquidity.
} 
moment in the future, or should the central bank be in the incapacity to buy bonds (for instance, if inflation takes off, or, in the US, if the Congress fails to agree on rising the debt ceiling), then these countries can also see their public debt shifting rapidly to the explosive path.

Besancenot, Huynh and Vranceanu (2004) have argued that in the very plausible case where the government's income is uncertain and there is no 'lender-of-last-resort', the maximum debt that a government can issue without risking illiquidity default is much lower than commonly thought; in particular, for the Euro area it could be much lower than the 60 per cent of GDP required by the S\&G Pact. At that time such calls for conservative management of public debt were seen as useful advice for emerging economies, but not as something that should be of interest for rich country governments.

Finally, one should notice that in the first year of the Euro, institutional investors were not able to identify differences in default risks between the Euro area governments; all governments could borrow at the same low interest rates. One important consequence of this 'risk illusion' was the heavy investment of various banks in Treasury bonds issued by foreign Euro area governments. For instance, in 2009, German and French banks held a large chunk of the Greek sovereign debt and Spanish banks held important amounts of Portuguese bonds. These cross-country investments originate a systemic risk, where the default of one government could trigger default of banks in other countries, and impose heavy losses on their governments should they decide to bail out their banks. As the crisis continued, by 2012 banks reduced their investment in foreign bonds, but increased the investment in national bonds. The risk of contagion via the bank channel has probably diminished, but did not completely disappear.

Unfortunately, the recent difficulties of many Euro area countries proved that a high private wealth per capita and a government made-up of professionals are not enough to insulate countries from the curse of multiple equilibria in public debt management. At the $(-1)$ level of the crisis, we found the abnormal rise in deficits and public debts triggered by the Great Recession. At the (-2) level, one should question why governments cannot stabilize their debt-to-GDP ratio over the business cycle, and what should be the role of the ECB in maintaining the financial stability of the Euro area. At the deeper (-3) level, we can ask whether the existing fiscal and monetary organization of the Euro area can survive through this crisis.

\section{The sovereign debt crisis 2010-2012}

\subsection{A complex situation}

The 2007-2009 Great Recession left behind a dramatic legacy for the Euro area: creeping growth and high long-term unemployment rates, a more fragile banking sector loaded with bad loans and huge public debts. Some countries are facing tremendous difficulties. Besides Greece that has already partially defaulted on sovereign debt held by private investors, high and volatile yields on government bonds and poor growth are compounding their effects in the most disruptive way in Portugal, Spain and Italy (see figure 5). Ireland also suffered a tremendous shock with a collapsing banking sector; at the end of 2012 it seems to have succeeded in redressing the economy, although it still faces many difficulties. At the opposite range of the spectrum, Germany imposed itself as a 'safe harbor' for investors, and has seen yields on short-term Government bonds sometimes falling below zero! The other Euro area 
countries navigate in between the two extremes, knowing that no government can claim victory, insofar as growth prospects keep on being sluggish, and debt-to-GDP is rising. With the exception of Germany and Finland, all other Euro area countries have met at some point in the 2010-2012 interval some difficulties in refinancing their debts. To be very precise, on November 2011 even Germany was surprised to see that it cannot sell all of its new debt, a reminder that no high-debt country (80 per cent of GDP at that time) is fully insulated from the risk of illiquidity.

As a sign of major distress, Greece, Ireland, Portugal and Spain were all forced to apply for EU emergency aids, and Italy avoided at the last minute a run on its public debt in 2012.

If we consider Greece as a special case of outright insolvency, there are many specific factors that could explain the dramatic situation of Spain, Portugal, Ireland and Italy. These countries are probably solvent but illiquid, i.e. private investors shun their bonds, although over a long period the government could pay back its debts. Both Spain and Ireland had to cope with the burst of a housing bubble when defaulting mortgage loans destroyed a large proportion of their banking sector. Rigid labor markets in Spain, Portugal and Italy, with high insider job protection, pushed up unit labor costs and eroded firm competitiveness in the last 15 years. In turn, high unemployment rates further push up deficits, and cast doubts on the ability of these governments to comply with deficit reduction targets.

France, the second largest economy in the Euro area, is an intriguing case. So far (December 2012) yields on French Treasury bonds are extremely low (including on 10-year bonds) and the French Treasury can sell its bonds without any rationing. However, with low growth and a declining competiveness, high unemployment, a rigid (and dual) labor market specific to Southern Europe, a huge public spending-toGDP ratio and a rising public debt, the global economic outlook is worrisome. Successive governments felt investors' nervousness, and pushed ahead measures aiming to reduce the state liabilities: a pension reform was implemented in 2009, and from 2010 governments have been pursuing a policy of fiscal restraint that should bring the deficit-to-GDP back to 3 per cent by 2013.

There is a shared opinion that Euro area countries should do whatever it takes to convince private investors that they can safely buy Euro area bonds. However, when it turns to deciding what should be done, it is difficult to reach a consensus since: (1) EU citizens do not share the same views on what the EU should be and the purpose of the monetary union; (2) neither policymakers nor economists share the same views on what the right steps to fight illiquidity are; (3) EU peoples do not agree on how to share the burden of the adjustment required by the crisis, which in turn gives rise to conflicts and tensions about the role of the ECB and of any would-be common budget.

We come back to the basic call for caution issued by Milton Friedman ten years ago. Subject to a major shock that affected their economies in a different way, with limited cross-country labor mobility, no cross-border social transfers, no independent exchange rate policy, no specific monetary policy, and limited capacity to raise public spending, in the short and medium run, countries can restore competiveness only in the hard way, by reducing nominal (and real) wages. Countries with relatively rigid labor markets and a tradition of social protest -- as is the case of Greece and other Southern European countries -- may not be able to achieve this adjustment. 
On top of this, with a central bank that cannot bail out distressed governments, interest rates on public debt are driven by investors' expectations, and nothing can rule out the default self-fulfilling equilibrium (see the Theory section). If there is one lesson to be learned from the on-going crisis, we now know that under the existing organization of the Euro area, financial stability can be achieved only if in normal times member countries present a public debt much lower than the commonly agreed 60 per cent of GDP.

\subsection{National initiatives}

In practice, starting with 2010 all governments have implemented fiscal consolidation programs, with the aim to reach a 3 per cent deficit-to-GDP ratio by 2013 or 2014 (2015 for the most affected countries) and place their public debt on the sustainable path (provided that interest rates do not edge up). This required drastic cuts in public spending - that mostly involved a reduction in the numbers and wages of civil servants, and higher taxes, mostly the VAT, a tax that is impacting both local and imported goods. But fiscal austerity affected growth in the short run, which put additional strain on those governments. There is an ongoing debate in the Euro area about the strengths and weaknesses of fiscal consolidation in a period of low growth/high unemployment.

With ECB target interest rate close to zero, in the early months of 2012, several economists, echoed by main political leaders from Southern EU countries, argued that only a massive fiscal stimulus could boost the weakest economies. Such recommendations build on the traditional Keynesian analysis according to which low (short-term) interest rates combined with a depressed economy signal an excess of savings over investment opportunities; in this context, a higher public spending and the connected deficit should not push up interest rates, but stimulate growth (Krugman, 2011).

Yet the Keynesian policy framework was developed under the assumption that Treasury bonds and money are perfect substitutes; in particular, Treasury bonds were seen as the risk-free asset. The contemporary new Keynesian macroeconomics also builds on the assumption that the central bank can maintain short and long-term interest rates on a pre-committed schedule. Yet these days are gone. Public debt is no longer a perfect hedge against financial risks, in particular in Euro area countries, where the central bank cannot monetize public debt. The default probability should be increasing with both debt and deficits, and the impact of the two variables should reinforce each other. Thus, a higher deficit should push up interest rates, and the variation should be bigger in high debt countries than in low debt countries. Furthermore, in 'high-risk' countries yields on corporate and public debt are highly correlated. Indeed, in Europe many corporations depend on public orders, subsidies and state guarantees. Under imperfect information, many investors use the country's risk as a proxy for corporate risk, in particular for small, non-listed firms. The best corporate rating is capped by the country rating; with successive downgrades of public debt, corporate financing costs have increased substantially in peripheral EU countries (IMF, 2012). If we put together these elements, in countries that run excessively high debts, close to the perceived sustainable level, any small increase in this debt resulting from the fiscal stimulation of the economy could bring about a substantial increase in interest rates. In turn, higher corporate interest rates would entail the crowding-out of private investment. If the negative 'financial crowding-out' effect takes over the direct positive public spending effect, the fiscal multiplier can even become negative. 
Vranceanu and Besancenot (2013) analyze the relationship between growth rates, public spending, and public debt using a panel of 26 EU countries over the period 1996-2011. In comparison with former studies, they focus more on the effectiveness of fiscal policies in high debt countries. A fixed effects panel regression shows that, all things being equal, a 10 percentage point increase in the debt-to-GDP ratio would bring down the growth rate by 0.28 percentage point on average; ${ }^{2}$ if the debt-to-GDP is above 150 per cent -- larger deficits (and higher spending) have a negative impact on growth rates in the year when they occur; around the contemporary average of 90 per cent debt-to-GDP ratio, the impact of higher spending on growth would be positive but small.

Here, it is worth mentioning the example of Ireland. In this country, the whole banking sector collapsed in 2010, after the burst in 2009 of a huge housing bubble financed with cheap bank loans. In 2009 the GDP fell by seven per cent, and the public deficit reached 14 per cent. The Irish government, which had committed to bail out all bank liabilities, needed to borrow billions of euro. This was too much for such a small country, and only an emergency loan by the EFSF ( 85 billion euro) allowed the government to continue its operations. The one-off transfer to banks raised the deficit to 31.2 per cent of GDP; public debt soared from 65 per cent in 2009 to 92.5 per cent of GDP in 2010. To restore market confidence and also generate resources needed to pay back the debt, the Irish government introduced a dramatic austerity program.

As summarized by the IMF (2012b), in the 2009-2012 period budgetary consolidation measures produced an eight per cent of GDP improvement in the structural primary balance of Ireland. Two-thirds of total adjustment fell on the expenditure side: they include a 14 per cent cut in public wages; an 8 per cent cut in welfare rates (except pensions); an almost 10 per cent reduction in public service numbers from their 2008 peak; and savings in the non-pay current and capital budgets. Revenue contributions have included personal income tax base broadening (10 per cent reduction in income tax bands, introduction of universal social charge, elimination of Pay-Related Social Insurance reliefs and exemptions); higher taxes on capital and savings; and an increase in indirect taxes, most notably, the 2 percentage point hike in the standard VAT rate to 23 per cent in 2012. The Irish government opposed all demands of the EU to raise the corporate tax rate, the lowest in Europe at12.5 per cent of profits.

Despite this huge adjustment, in 2011 the Irish economy grew again by 0.7 per cent, and GDP growth for 2012 is expected to be positive too, at about 0.6 per cent. If in both years private consumption growth was in the negative territory, export growth was quite strong at 4 per cent in 2010, despite a strong euro. Fiscal consolidation and positive growth make realistic the projections of the government, according to which the deficit-to-GDP ratio can fall back to 3 per cent by 2015. Even if the access to the capital market is still closed (except for very short terms notes), at the end of 2012 yields on 10-year bonds reached a "normal" level (Figure 8).

All in all, Ireland faced one extremely powerful crisis, having to manage both the burst in the housing bubble and the consecutive financial distress. A rigorous management of the crisis by the government

\footnotetext{
${ }^{2}$ Several studies have shown that a large public debt (in general above 90 per cent of GDP) is associated to poor growth performance of the economy. See for instance Reinhart and Rogoff (2010), Kumar and Woo (2010), Checherita-Westphal and Rother (2012) and Baum et al. (2012).
} 
and a population that understood and backed the most painful measures seem to be the key for a rapid recovery of an economy that has strong fundamentals.

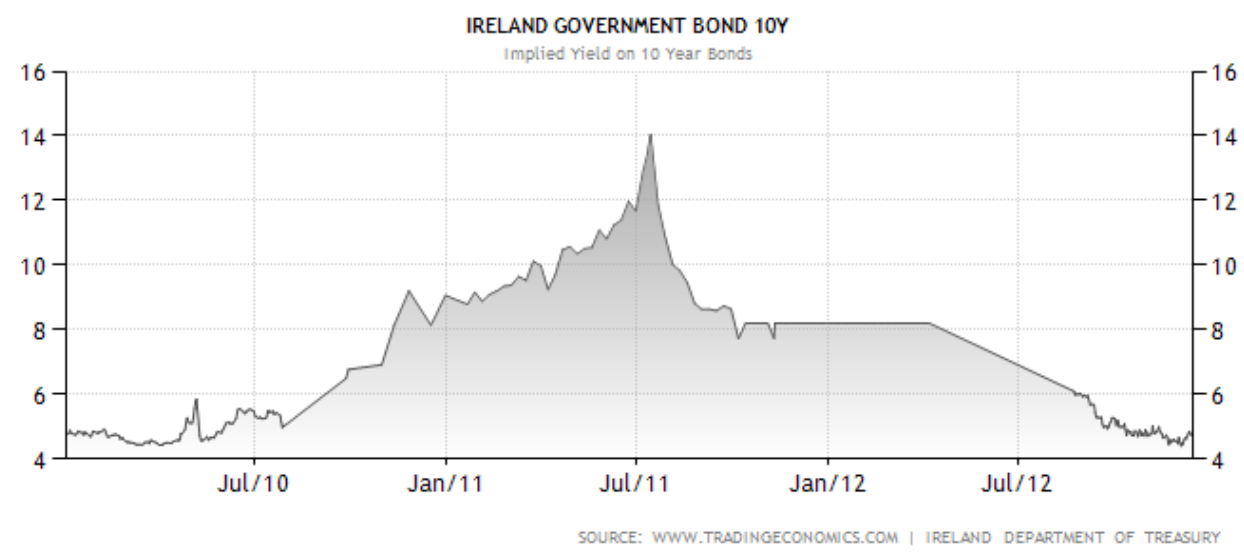

Figure 8. Ireland 10-year Government bond yield. Source: Trading Economics (accessed 14.12.2012).

\subsection{The EU collective action}

Turning now to the EU response to the sovereign debt crisis, we can group it in active measures and new rules. Active measures include a series of programs through which various EU institutions provide liquidity to distressed governments (credit lines, or emergency purchase of bonds). New rules aim to forbid actions that seem to be at the origin of the crisis (such as excessive deficits), and thus try to restore trust.

One important element in the EU strategy of active support to distressed governments was the creation in 2009 of the European Financial Stability Facility (EFSF) that was transformed on October 2012 into a permanent facility, the European Stability Mechanism (ESM) with a borrowing capacity up to 700 billion euro. The EFSF and now the ESM can raise funds in capital markets with the collective guarantee of Euro area member states. They can use the funds to provide conditional support to distressed governments (and banks now). For instance, in 2010, with markets for public debt almost closed, Portugal and Ireland were close to default (they could not roll over their public debt). To avoid this dramatic outcome, the EFSF provided their governments with emergency loans conditional on implementation of tough fiscal consolidation programs, as it did for Greece (85 billion euro loan to Ireland in December 2010; 78 billion euro loan to Portugal in Mai 2011). In May 2012 the EFSF further provided a 100 billion euro grant to Spain in order to support its ailing banking sector. So far, the German guarantee, and to some extent the French one, have allowed the fund to borrow at low interest rates. So far, rating agencies seem to relate the fund's rating to that of the second main guarantor which is France (thus the ESM is no longer a triple-A borrower). Furthermore, any default on funds provided by the EFSF/ESM would harm both the fund rating, and that of its main guarantors. 
The institution that drags all hopes and fears is the European Central Bank. It goes beyond the scope of this short chapter to provide an exhaustive account of the ECB multiple actions during the Great Recession $^{3}$ and the Euro sovereign debt crisis; we will focus only on the most important elements.

In its first years the ECB behaved as an example of monetary orthodoxy; during the Great Recession it avoided buying massive amounts of Treasury bonds or Mortgage Backed Securities, as did the Fed or the Bank of England under their 'quantitative easing' programs. It is true, in 2008-2009 the ECB massively raised the amount and length of collateralized loans to the banking sector, but was on track to reverse these operations when the Euro sovereign debt crisis began (the total balance sheet of the ECB rose from 1250 billion euro in September 2007 to 1820 billion euro in September 2009)

Today the debt crisis is taking a heavy toll on the ECB orthodoxy. True, the inflation rate today is close to the medium run two per cent target, so the bank can focus on the financial stability goal. As long as the price stability goal and the financial stability goal do not diverge, this choice is legitimate. However, in the last three years the balance sheet of the ECB rose by 65 per cent to reach 3000 billion euro in September 2012 (about 33 per cent of Euro area GDP, compared with 19 per cent of GDP for the Fed). The risk of inflation in the long run is higher than many policymakers want us to believe; furthermore, should inflation point its nose, the ECB will notice that its ability to pursue the price stability goal has been undermined by the special measures it took in the last period.

In particular, in December 2011 and February 2012, at a period where tensions on Spanish and Italian debt reached again a peak (interest rates on 10-year bonds crossed the seven per cent scary bar), the ECB carried out two 'surprise' Long Term Refinancing Operations, which provided EU banks 3-year loans against collateral for a total of roughly 1000 billion euro. Banks used a fraction of this sum to invest in high-risk high-yield Treasuries, and, for a short period, the price of these assets went up. Whether Spanish and Italian banks made this choice free from any influence from their governments it is not clear. But the bulk of the amount was served to the most fragile banks to keep financing their operations in a context where they cannot access the interbank money market. From a monetary policy management, it is important to notice that these huge amounts are locked for three years; in the meantime the ECB will not be able to withdraw them easily. ${ }^{4}$

\footnotetext{
${ }^{3}$ For a short presentation of the ECB action during the Great Recession, see Vranceanu (2010).

${ }^{4}$ Banks have the option to reimburse in advance these loans.
} 


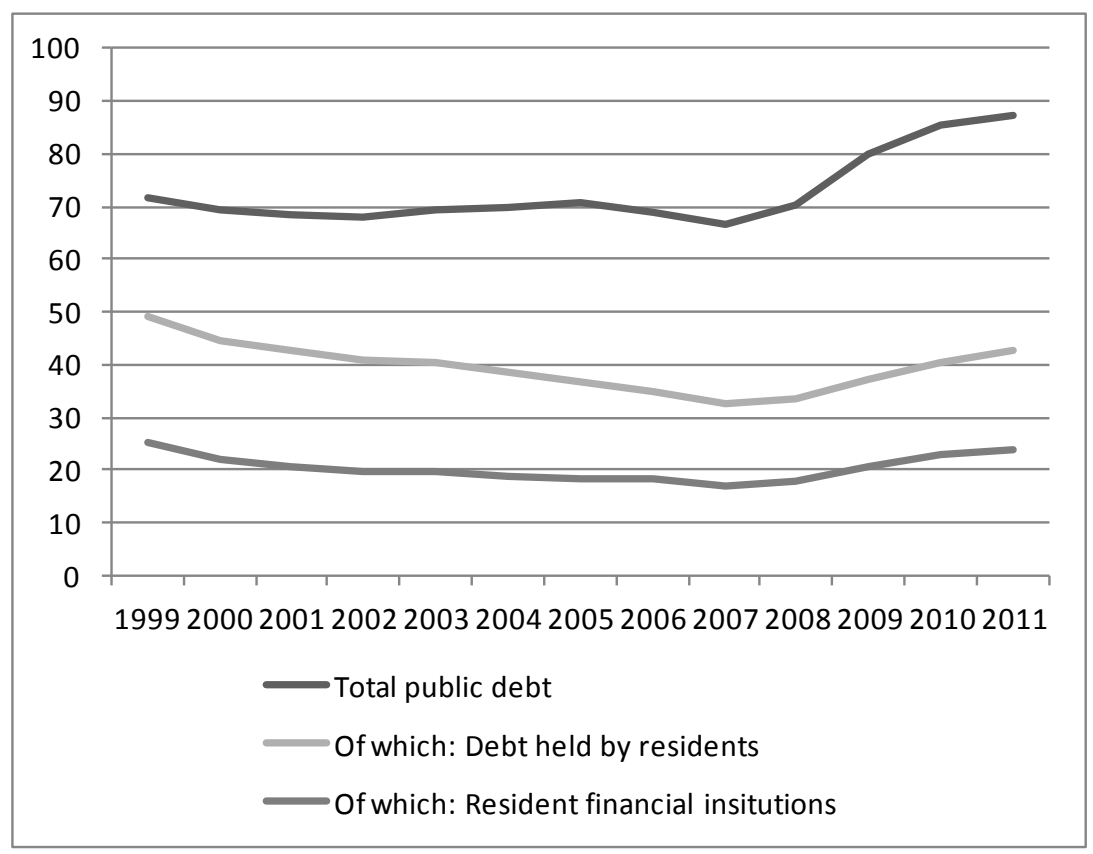

Figure 9. Total public debt as a percentage of GDP, of which public debt held by residents, and, among residents, by resident financial institutions. Source: $E C B$

The Maastricht Treaty and the Statutes of the ECB prevent this institution to bail out a government that cannot sell its bonds. The ECB officials interpreted this ban as a commitment not to buy debt in primary markets (i.e., cannot 'monetize' debt). The ECB used to claim that providing loans to commercial banks against collateral bonds from distressed but not fully defaulting government is a different thing, since banks ultimately bear the risk of sovereign default. But this requires that banks have enough equity to cover such losses. Should banks themselves default, the ECB would have to bear the losses. Today many banks in the Euro area are very fragile and live on the ECB credit lines (mainly in Greece, Portugal, Spain, Ireland). The difference between outright purchases of bonds and collateralized lending to weak banks is much thinner than the ECB officials want us to believe. ${ }^{5}$

Furthermore, given the mounting tensions on Italian and Spanish bonds in the summer of 2012, Mario Draghi, the President of the ECB, completely reversed the traditional position of the ECB; in a remarked speech in London on July 12th, he stated the ECB will do 'whatever it takes to protect the Euro'. In September 2012, the ECB introduced the Outright Monetary Transactions (OMT) program that allows the ECB to buy in the secondary market unlimited amounts of distressed bonds with 3-year maturity and below, provided that the respective government has applied for the ESM aid (and thus entered a fiscal consolidation agreement with the ESM-IMF). So far, the simple announcement of the measure has brought down interest rates in Spain and Italy, and, by the magic of self-fulfilling expectations, made the intervention of the bank unnecessary. However, if national governments cannot comply with their

\footnotetext{
${ }^{5}$ As an exception to the no-bail out rule, since May 2010 and until March 2012 the ECB went into the markets and bought about 200 billion euro distressed bonds under the now closed Securities Markets Program.
} 
deficit reduction targets, it is highly probable that investors will run again and the ECB will have to act. Of course, with an inflation rate close to two per cent, the commitment of the ECB is credible today. However, if ever inflation deviates from the target, the ECB would find itself in a corner.

Finally, in many developed countries there is an unhealthy complicity between national banks and the government, with a flavor of cronyism. Despite the commitment of the EU for developing a single market in services (including banking), until recently all governments strived to keep the 'supervision' and regulation of banks under their responsibility. It is true, big banks from Germany, France, Austria and Spain absorbed many banks in the poorer EU countries. However, mergers between banks in the rich EU countries almost never happened before the Great Recession. As a consequence, the EU market in banking services was extremely fragmented. The Euro debt crisis has exposed the notorious sins of this complicity: governments support failing banks with state borrowed funds, and banks buy substantial amounts of high-yield distressed public debt with cheap loans provided by the ECB, bringing these bonds as collateral. Should weak banks never recover, someone will have to take the losses. If governments can take them, then taxpayers will end up paying the bill. If not, losses will be transferred to the central bank, and the losses will be shared among the euro user through inflation. As agreed at an EU summit in December 2012, a single EU banking supervision board, in charge with regulation of large banks throughout the Euro area will get into operation in 2013.

Many EU leaders realize now that the sustainability of this weird economic construct which is the European Monetary Union critically depends on an extremely conservative management of the public debt. Hence, on 2 March 2012 all European leaders (except Czech Republic and the United Kingdom, which are not in the Euro area) agreed on the implementation by January 2013 of a new fiscal stability treaty, the Fiscal Compact, as a stricter version of the former Stability and Growth Pact. To make it appear more serious than the S\&GP, EU leaders agreed to carve the Fiscal Compact into national laws or constitutions. The new Treaty requires governments to run a structural deficit of less than 0.5 per cent (respectively one per cent) of GDP if the debt level is above (below) 60 per cent of GDP. The treaty also introduces a rule for reducing public debt when it exceeds 60 per cent of GDP. The European Court of Justice can impose a fine of up to 0.1 per cent of GDP if countries breach the Treaty.

As is the case with all international Treaties, it is not clear how sanctions can be enforced. What will happen if government of a big country does not comply with the new pact? Does the EU have enough strength to impose and collect the fine? And how a distressed government can pay a fine that would raise its burden and thus its chances to default?

\section{Conclusion}

This chapter presented some of the most important elements of the sovereign debt crisis that has been shaking the whole Euro region since the late 2009. Theoretical arguments suggest that in absence of a genuine lender-of-last-resort, no country with a large debt-to-GDP ratio can be fully insulated from the risk of illiquidity.

What can be done in order to restore the financial stability of the Euro area depends to a large extent on political factors. In theory, centralizing taxation and spending at the EU level would be the natural step 
ahead, and it is not surprising that the European Commission is pushing in that direction. But many European citizens dislike this solution. Political support to create a fiscal union with uniform taxation and spending rules is very limited.

Some politicians ask for the EU to issue 'Eurobonds', i.e., create another vehicle at the EU level (in some respect, similar to the ESM) that can borrow in the international markets with multilateral guarantees. The vehicle would transfer the proceedings to national governments to do whatever they want, and use a joint flow of taxes to service the debt. Thus, spending would sit with national policymakers, while at least a fraction of the flow of tax income would be mutualized. Hence, if at one moment, one government cannot fulfill its obligations, the other governments could fill the gap, so lenders would not be exposed to the default risk. This is a weird solution: since the problem of many governments is that they spend too much (compared to their income), why should they behave more responsibly if they get access to a source of cheap money backed by the credibility of rigorous governments? Such mechanism could only foster the natural tendency of Euro governments to free ride on the back of EU institutions.

Today the ECB has accepted to bail out the most distressed governments (via the OMT program), provided that the country agrees to implement a consolidation program under external supervision (ESM, IMF). So far the OMT program has not been tested. In particular, who can make sure that the fiscal commitment of a government will not be turned down by street protesters or rising extremist parties? If so, why not to take the argument one step ahead and decide to bail out any distressed government, in an unlimited amount and without any condition? The US Fed and the Bank of England can well proceed in this way. Well, the situation is not quite similar. In the US or UK, if the central bank buys huge amounts of bonds, it exposes its own citizens to the risk (and reality) of inflation. If the ECB buys large amounts of bonds of distressed Euro area governments, it exposes citizens from all Euro areas to inflation, including those from the rigorous countries. The latter would have a substantial interest to quit the Euro.

Unfortunately, there are not too many solutions left. One would be the orderly and partial disintegration of the monetary union. After the Great Recession, it became obvious that small EU economies, such as many Eastern European countries, get high benefits from allowing their currency to depreciate against the euro. Countries under a 'fixed exchange rate regime' such as Portugal, Greece, Ireland, were the most affected by the crisis. Probably the dominant political parties in Europe, who were strong advocates of the Euro, will not accept the disintegration solution. However, poorer EU countries from Eastern Europe should be given much more time (fifteen years at least) before they join the Euro area.

Another solution would require all euro area governments to voluntary commit on pursuing a conservative fiscal policy that goes much beyond the going standards. One important lesson from the going sovereign debt crisis is that even 60 per cent of GDP might be an unsustainable debt in the conditions where there is no genuine 'lender-of-last-resort'. For sure, bringing debt below the 60 per cent level will take many years and many sacrifices; governments should lead the example by reducing their huge spending bias. Whether voters will allow them to follow this way is to be seen. One thing is sure: the debt-powered growth era is over. 


\section{References}

Baum, Anja, Cristina Checherita-Westphal and Philipp Rother, 2012, Debt and growth: New evidence for the Euro area, Journal of International Money and Finance, Available online at: 10.1016/j.jimonfin.2012.07.004.

Besancenot, Damien, Kim Huynh and Radu Vranceanu, 2004, Default on sustainable public debt: illiquidity suspect convicted, Economics Letters, 82, 2, pp. 205-211.

Checherita-Westphal, Cristina and Philipp Rother, 2012, The impact of high government debt on economic growth and its channels: An empirical investigation for the Euro area, European Economic Review, 56, 7, pp. 1392-1405.

Cecchetti, Stephen G., M. S. Mohanty and Fabrizio Zampolli, The future of public debt: Prospects and implications, presented to the Reserve Bank of India's International Research Conference 'Challenges to Central Banking in the context of Financial Crisis,' Mumbai, India on 12-13 February 2010. http://195.211.73.19/ birchcc/images/uploads/BIS_Implications_Debt_Crisis.pdf

Coeuré, Benoit, 2012, The euro area sovereign market: lessons from the crisis, Speech to the 12th IMF Annual Forum on Managing Sovereign Risk and Public Debt, Rio de Janeiro, 28-29 June 2012, Availble online at: http://www.ecb.int/press/key/date/2012/html/sp120628 1.en.html.

European Commission, 2011, Employment and Social Developments in Europe 2011, Publications Office of the European Union, Luxembourg.

Fourçans, André and Radu Vranceanu, 2007, The ECB monetary policy: choices and challenges, Journal of Policy Modeling, 29, 2, pp. 181-194.

IMF, 2012, Global Financial Stability Report. Restoring Confidence and Progressing on Reforms, October 2012, International Monetary Fund, Washington DC.

IMF, 2012b, Ireland: Selected Issues, IMF Country Report No. 12/265, International Monetary Fund, Washington DC.

Mundell, Robert and Milton Friedman, 2001, One world, one money?, Options Politiques, Available online: www.irpp.org/po/archive/may01/friedman.pdf.

Reinhart, Carmen and Kenneth S. Rogoff, 2009, This Time is Different: Eight Centuries of Financial Folly, Princeton University Press, Princeton, NJ.

Reinhart, Carmen and Kenneth S. Rogoff, 2010, Growth in a time of debt, American Economic Review, 100, 2, pp. 573-578.

Kumar, Manmohan S. and Jaejoon Woo, 2010, Public debt and growth, IMF Working Paper, WP/10/174 International Monetary Fund, Washington DC. 
Krugman, Paul, 2011, Mr. Keynes and the moderns, VOX, 21 June, Available online at: www.voxeu.org/ article/ mr-keynes-and-moderns. Accessed: 15.10.2012

Vranceanu, Radu and Damien Besancenot, 2013, The spending multiplier in a time of massive public debt: the Euro area case, Applied Economics Letters, 20, pp. 758-762.

Vranceanu, Radu, 2011, Four myths and a financial crisis, 2011, Thunderbird International Business Review, 53, 2, pp. 151-171.

Wouter Botzen, W. J. and Philip S. Marey, 2010, Did the ECB respond to the stock market before the crisis?, Journal of Policy Modeling, 32, 3, pp. 303-322. 
ESSEC Business School Avenue Bernard Hirsch BP 50105

95021 Cergy-Pontoise Cedex

France

Tél. +33(0)134433000

$\mathrm{Fax}+33(0) 134433001$

www.essec.fr

\section{ESSEC Executive Education} CNIT BP 230

92053 Paris-La Défense France

Têl. +33(0)146924900

Fax +33(0)1 46924990

http://formation.essec.fr

ESSEC Business School

Singapore Campus

100 Victoria Street

National Library Building \# 13-02

Singapore 188064

essecasia@essec.fr

Tél. +6568849780

Fax +6568849781

www.essec.edu

Informations

Alison Bougi

+33 (0)134433358

bougi@essec.fr

www.essec.fr

research.center@essec.fr

ISSN 1291-9616 